\title{
Antibacterial Activity of Plant Defensins
}

\author{
Andrew E. Sathoff ${ }^{1, \dagger}$ and Deborah A. Samac ${ }^{1,2}$ \\ ${ }^{1}$ Department of Plant Pathology, 1991 Upper Buford Circle, University of Minnesota, St. Paul, MN, 55108, U.S.A.; and \\ ${ }^{2}$ USDA-ARS, Plant Science Research Unit, 1991 Upper Buford Circle, St. Paul, MN 55108, U.S.A.
}

Accepted 19 November 2018.

\begin{abstract}
Plant defensins are antimicrobial host defense peptides expressed in all higher plants. Performing a significant role in plant innate immunity, plant defensins display potent activity against a wide range of pathogens. Vertebrate and invertebrate defensins have well-characterized antibacterial activity, but plant defensins are commonly considered to display antimicrobial activity against only fungi. In this review, we highlight the often-overlooked antibacterial activity of plant defensins. Also, we illustrate methods to evaluate defensins for antibacterial activity and describe the current advances in uncovering their antibacterial modes of action.
\end{abstract}

Plants produce a wide array of antimicrobial peptides (AMPs) constitutively or in response to pathogen infection, abiotic stresses, and mechanical injury, including damage from insects and herbivores. Plant AMPs are classified based on their structure and presence of disulfide bonds into the main classes of cyclotides, defensins, hevein-like proteins, lipid transfer proteins, snakins, thionins, and vicilin-like proteins (Goyal and Mattoo 2014). The plant defensins are among the best-characterized of the AMPs, with an abundance of representatives from diverse plant species (Tam et al. 2015). The term plant defensin was coined due to structural and functional homology of the plant peptides to insect and human defensins (Broekaert et al. 1995). Plant defensins are cationic, with a basic isoelectric point (pI), and are identified by an invariant tetradisulfide array. Although they share little amino acid sequence identity, these peptides share a conserved three-dimensional structure consisting of one $\alpha$-helix and three antiparallel $\beta$-strands that are connected by four disulfide bonds, which forms a distinctive cysteine-stabilized $\alpha \beta$ $(\mathrm{CS} \alpha \beta)$ motif. Defensins from plants, fungi, and invertebrates share the $\operatorname{CS} \alpha \beta$ motif, which defines the cis-defensin superfamily, distinct from the trans-defensin superfamily, consisting of vertebrate $\alpha-, \beta-, \theta-$, and invertebrate big defensins (Shafee et al. 2016). Proteins in the two defensin superfamilies likely arose from extensive convergent evolution (Shafee et al. 2016). Plant defensins possess an additional conserved sequence, a $\gamma$-core motif, defined as $\mathrm{GXCX}_{3-9} \mathrm{C}$, that is required for their antifungal activity (Sagaram et al. 2011). Plant defensins have been shown to be promiscuous peptides, meaning that a single defensin peptide can have multiple functions (van der Weerden and Anderson 2013). For example, in addition to antimicrobial

${ }^{\dagger}$ Corresponding author: A. E. Sathoff; satho002@umn.edu

Funding: This work is supported by the United States Department of Agriculture-Agricultural Research Service project 5026-12210-002-00D.

(C) 2019 The American Phytopathological Society activity, defensins with diverse functions, such as amylase activity, conferring zinc tolerance, and involvement in pollen tube elongation have been identified (Carvalho and Gomes 2009; Franco 2011). Though plant defensins share a common tertiary structure, there is extensive variation in amino acid sequences and length of peptides. This sequence diversity corresponds to variation in antimicrobial activity.

Numerous recent review papers have summarized the extensive antifungal activity of plant defensins and their mode of action against fungi, but these reviews do not acknowledge antibacterial activity or only cite an example without going into detail (Cools et al. 2017; De Coninck et al. 2013; Lacerda et al. 2014; Montesinos 2007; Parisi et al. 2018; Rautenbach et al. 2016; Vriens et al. 2014). The lack of information on the antibacterial activity of plant defensins is surprising because plant defensins were originally classified as $\gamma$-thionins, a subclass of thionins, which have long been known to have antibacterial activity. Purothionins extracted from wheat (Triticum aestivum) display extensive antibacterial activity against both grampositive and gram-negative strains of phytopathogenic bacteria (Fernandez de Caleya et al. 1972). Additionally, human and invertebrate defensins have potent antibacterial activity (Ageitos et al. 2017), and the mode of action (MOA) of these defensins against bacterial pathogens is well characterized (Ageitos et al. 2017; Guilhelmelli et al. 2013). Vertebrate defensins rely on electrostatic interactions with the anionic lipid components of bacterial membranes, which leads to rapid membrane permeabilization through pore formation (Morgera et al. 2008), which is a MOA for many other AMPs. For example, HNP-1, the most studied human $\alpha$-defensin, has an antibacterial MOA similar to several other vertebrate defensins that occurs via HNP-1 dimerization, then, electrostatic interaction of dimers with the bacterial membrane in which $\beta$-sheet dimers span the membrane forming a pore, with higher order oligomers of HNP-1 forming upon dimers when the defensin is in high concentration (Zhang et al. 2010). Another well-studied antibacterial human defensin, human $\beta$-defensin-3 (HBD3), has been shown to inhibit bacterial cell-wall biosynthesis by interacting with lipid II components, which allows for HBD3 to have widespread activity against both grampositive and gram-negative bacteria (Sass et al. 2008).

Frequently, plant defensins display antifungal activity and lack antibacterial activity. For example, Lc-Def from lentil (Lens culinaris), showed antifungal activity but failed to show activity against either gram-positive (Clavibacter michiganensis) or gram-negative (Agrobacterium tumefaciens and Pseudomonas syringae) bacterial plant pathogens (Shenkarev et al. 2014). However, it is likely that many defensins have not been tested for antibacterial activity or the testing method used may have led to the conclusion that the defensin lacked antibacterial activity. The focus on antifungal activity may reflect 
the relative importance of fungal pathogens as opposed to bacterial pathogens in plant pathogenesis compared with human and animal disease. Because of their potent antifungal activity, plant defensins are being exploited in agricultural biotechnological applications to generate disease-resistant crops (Gao et al. 2000; Gaspar et al. 2014; Sharma et al. 2018).

Though fungal plant pathogens may be more prevalent, plant-pathogenic bacteria have great economic significance and influence over food security (Mansfield et al. 2012). Ralstonia solanacearum has a broad host range, infecting over 200 plant species, including important food crops such as potato, banana, and tomato. From potato alone, the yearly worldwide losses are estimated to be $\$ 1$ billion (Elphinstone 2005). During the monsoon season in India and Southeast Asia, outbreaks of bacterial leaf blight caused by Xanthomonas oryzae pv. oryzae reduce the yield of rice, a staple crop, by up to one half (Mew et al. 1993). There are a limited number of management strategies for controlling bacterial diseases of plants. Although genetic resistance to bacterial diseases can be found in many crops, it often is only effective against a single or small number of pathotypes (races), requiring "stacking" of numerous resistance genes, and genetic resistance can be overcome through mutagenesis in the pathogen. Antibiotic usage on crops is expensive and contributes to the generation of antibacterialresistant bacterial populations. Transgenic expression of antibacterial plant defensins would reduce producer application of costly antibiotics and be an eco-friendly method of disease control that may be difficult to overcome, depending on the specific MOA.

\section{PLANT DEFENSIN NOMENCLATURE}

The inconsistent naming of plant peptides with a defensin structure may have resulted in the loss of information on the defensins with antibacterial activity. Until recently, the term thionin was used synonymously with plant defensin in the small-grains literature. For example, a cold acclimationinduced, antibacterial plant peptide isolated from winter wheat (Triticum aestivum) crown tissue, Tad1, was referred to as being both a thionin and a plant defensin throughout its characterization (Koike et al. 2002). A thionin from potato (Solanum tuberosum) tubers, Pth-St1, which was named before the term plant defensin was developed, was shown to display broad-spectrum activity against fungi and gram-positive and gram-negative bacteria (Moreno et al. 1994). Cp-thionin II from cowpea (Vigna unguiculata) displays antibacterial activity against both gram-positive and gram-negative pathogens (Franco et al. 2006). Thionins and defensins are currently considered to be two separate classes of AMPs, but the naming conventions do not reflect this change of classification.

The following peptides have the structure of plant defensins but were given a wide variety of names using no particular system of nomenclature. ZmESR-6, isolated from kernels of Zea mays, shows antimicrobial activity against both fungi and bacteria (Balandín et al. 2005), with greater efficacy against gram-positive bacteria compared with gram-negative bacteria. Fabatin was isolated from broad bean (Vicia faba) seeds and displays activity against gram-positive and gram-negative bacteria but not fungi (Zhang and Lewis 1997). Fujimura et al. $(2003,2004)$ identified peptides from tulip (Tulipa gesneriana, Tu-AMP1 and Tu-AMP2) and buckwheat (Fagopyrum esculentum, Fa-AMP1 and Fa-AMP2) that have both antibacterial and antifungal activity. These cases highlight the need for a consistent nomenclature system for plant defensins. Renaming these previously discovered plant defensins would make them more accessible to the research community. Following the current naming conventions, a two-letter genus/species designation should be followed by a defensin indication (Def) and number. Renaming of plant defensins has already been done in a few cases. For example, the plant defensin alfAFP from alfalfa (Medicago sativa) was renamed MsDef1 (Spelbrink et al. 2004). Suggested new names for previously characterized peptides are listed in Table 1 .

\section{EVALUATING ANTIBACTERIAL ACTIVITY}

The antibacterial activity of a plant defensin can be described by different parameters determined by several distinct methods of testing. The selected experimental approach can obscure validation of plant defensin antibacterial activity. Frequently, in vitro assays are designed to find the minimal inhibitory concentration (MIC) of a defensin against the bacterium of interest. The MIC is defined as the concentration of an antimicrobial agent at which no bacterial growth is detected. MIC determination uses optical density to quantify bacterial growth and is often achieved through serial microdilution of agents in microplates with a defined number of bacterial cells (Wiegand et al. 2008). Slowing bacterial growth may result in a delayed bacterial infection, and that can be a desirable trait in crop production. Plant defensins may alter the kinetics of bacterial growth, which could be missed because MIC assays are influenced by inoculum concentration and cannot distinguish between bacteriostatic and bactericidal mechanisms. Additionally, MIC tests could lead to false negatives regarding the activity of a plant defensin if insufficient peptide is used to completely inhibit growth. To fully capture inhibitory activity of a defensin, including partial suppression of bacterial growth, a more appropriate method of evaluating antibacterial activity would be to measure the $\mathrm{IC}_{50}$ value, the concentration of defensin peptide that reduces bacterial growth by half. CFU-based assays are frequently utilized to determine $\mathrm{IC}_{50}$ values. Throughout this review, the antibacterial inhibitory concentrations will be carefully noted as an $\mathrm{IC}_{50}$ or MIC parameter (Table 1).

\section{ANTIBACTERIAL PLANT DEFENSINS}

Many of the first plant defensin peptides characterized were isolated from crude seed extracts. The defensins from the seeds of horticultural species from three plant families, horse chestnut (Aesculus hippocastanum, Ah-AMP1), butterfly pea (Clitoria ternatea, Ct-AMP1), and Dahlia merckii (Dm-AMP1, DmAMP2), were evaluated against four gram-positive bacterial species and two gram-negative bacterial species causing diseases in humans. Ah-AMP1, Ct-AMP1, and Dm-AMP1 inhibit Bacillus subtilis but not Escherichia coli, Micrococcus luteus, Proteus vulgaris, Staphylococcus aureus, or Streptococcus faecalis. Additionally, the $\mathrm{IC}_{50}$ values for inhibition of $B$. subtilis were relatively high, ranging from 15 to $150 \mu \mathrm{g} / \mathrm{ml}$ (Osborn et al. 1995). This limited antibacterial activity in this initial, fundamental study may have dissuaded other researchers from further antibacterial testing during the characterization of newly discovered plant defensins.

Spinach defensin (So-D2) is the most commonly referenced plant defensin with antibacterial activity. So-D2 and So-D7 were isolated from spinach (Spinacia oleracea) leaves and display antibacterial activity against Clavibacter sepedonicus and Ralstonia solanacearum, gram-positive and gram-negative plant-pathogenic bacteria, respectively (Segura et al. 1998). These defensins have potent activity against the bacterial isolates tested with $\mathrm{IC}_{50}$ values ranging from 0.1 to $2 \mu \mathrm{M}$. Also, So-D2 and So-D7 display activity against fungi with $\mathrm{IC}_{50}$ values of 9 and $11 \mu \mathrm{M}$, respectively, to Fusarium solani. The citrus industry has utilized these defensins to generate transgenic sweet orange and grapefruit trees through Agrobacterium-mediated transformation in hopes to combat 
economically important bacterial diseases. Transgenic citrus trees constitutively expressing So-D2 and So-D7 in combination were shown to be highly resistant to citrus greening caused by the bacterial pathogens 'Candidatus Liberibacter spp.' and to citrus canker caused by Xanthomonas axonopodis pv. citri (Mirkov and Gonzalez-Ramos 2014). Simultaneously expressing both spinach defensins resulted in significantly greater disease control than expression of an individual defensin. Disease resistance for citrus greening was determined by both grafting and psyllid inoculation greenhouse trials, and citrus canker resistance was assessed using a detached leaf assay. Additionally, Citrus tristeza virus (CTV) has been modified into a remarkably stable, viral vector to transfect citrus and provide long-term expression of spinach defensins (Kress 2015). In greenhouse studies, inoculation of citrus plants with the
CTV-based vector imparted resistance to both citrus greening and citrus canker. The CTV vector can be utilized as a microbial pesticide in the field, which is currently a disease control method approved by the United States Environmental Protection Agency. Synthetic AMPs, with structures similar to plant defensins, have also been utilized to control citrus greening and citrus canker (Hao et al. 2017).

Antibacterial activity was identified in OsDef7 and OsDef8, defensins from rice (Oryza sativa L. subsp. japonica) (Tantong et al. 2016). In contrast to the conventional method of testing activity of crude protein extracts, these defensins were first identified through an in silico coexpression network analysis of genes encoding defensin and defensin-like peptides. Using RiceArrayNet (Lee et al. 2009) with data collected from 183 rice microarrays, the putative defensins were found to be

Table 1. Comprehensive list of all plant defensins with antibacterial activity ${ }^{\mathrm{a}}$

\begin{tabular}{|c|c|c|c|c|c|}
\hline Peptide & Source & $\begin{array}{l}\text { Suggested defensin } \\
\text { nomenclature }\end{array}$ & Sensitive bacteria & $\mathrm{IC}_{50}{ }^{\mathrm{b}}$ & MIC $^{c}$ \\
\hline Ah-AMP1 (Osborn et al. 1995) & Aesculus hippocastanum & AhDef1 & Bacillus subtilis & $100 \mu \mathrm{g} / \mathrm{ml}$ & \\
\hline Cp-thionin II (Franco et al. 2006) & Vigna unguiculata & VuDef2 & $\begin{array}{l}\text { Pseudomonas syringae } \\
\text { Staphylococcus aureus } \\
\text { Escherichia coli }\end{array}$ & & $\begin{array}{r}42 \mu \mathrm{g} / \mathrm{ml} \\
128 \mu \mathrm{g} / \mathrm{ml} \\
64 \mu \mathrm{g} / \mathrm{ml}\end{array}$ \\
\hline Ct-AMP1 (Osborn et al. 1995) & Clitoria ternatea & CtDef1 & Bacillus subtilis & $15 \mu \mathrm{g} / \mathrm{ml}$ & \\
\hline Dm-AMP1 (Osborn et al. 1995) & Dahlia merckii & DmDef1 & Bacillus subtilis & $150 \mu \mathrm{g} / \mathrm{ml}$ & \\
\hline Fa-AMP1 (Fujimura et al. 2004) & Fagopyrum esculentum & FeDef1 & $\begin{array}{l}\text { Erwinia carotovora subsp. carotovora } \\
\text { Agrobacterium tumefaciens } \\
\text { Clavibacter michiganensis } \\
\text { Curtobacterium flaccumfaciens pv. oortii }\end{array}$ & $\begin{array}{l}11 \mu \mathrm{g} / \mathrm{ml} \\
24 \mu \mathrm{g} / \mathrm{ml} \\
14 \mu \mathrm{g} / \mathrm{ml} \\
13 \mu \mathrm{g} / \mathrm{ml}\end{array}$ & \\
\hline Fa-AMP2 (Fujimura et al. 2004) & Fagopyrum esculentum & FeDef2 & $\begin{array}{l}\text { Erwinia carotovora subsp. carotovora } \\
\text { Agrobacterium tumefaciens } \\
\text { Clavibacter michiganensis } \\
\text { Curtobacterium flaccumfaciens pv. oortii }\end{array}$ & $\begin{array}{l}15 \mu \mathrm{g} / \mathrm{ml} \\
17 \mu \mathrm{g} / \mathrm{ml} \\
17 \mu \mathrm{g} / \mathrm{ml} \\
15 \mu \mathrm{g} / \mathrm{ml}\end{array}$ & \\
\hline Fabatin (Zhang and Lewis 1997) & Vicia faba & VfDef1 & $\begin{array}{l}\text { Escherichia coli } \\
\text { Enterococcus hirae } \\
\text { Pseudomonas aeruginosa }\end{array}$ & $\begin{array}{c}14.53 \mu \mathrm{g} / \mathrm{ml} \\
28.75 \mu \mathrm{g} / \mathrm{ml} \\
0.8 \mu \mathrm{g} / \mathrm{ml}\end{array}$ & \\
\hline J1-1 (Guillén-Chable et al. 2017) & Capsicum аппиит & CaDef1 & Pseudomonas aeruginosa & & $250 \mu \mathrm{g} / \mathrm{ml}$ \\
\hline Limenin (Wong and Ng 2006) & Phaseolus limensis & PIDef1 & $\begin{array}{l}\text { Mycobacterium phlei } \\
\text { Proteus vulgaris } \\
\text { Bacillus megaterium } \\
\text { Bacillus subtilis }\end{array}$ & $\begin{array}{r}96 \mu \mathrm{M} \\
81 \mu \mathrm{M} \\
102 \mu \mathrm{M} \\
112 \mu \mathrm{M}\end{array}$ & \\
\hline MtDef5 (Velivelli et al. 2018) & Medicago truncatula & - & Xanthomonas campestris pv. campestris & & $6 \mu \mathrm{M}$ \\
\hline OsDef7 (Tantong et al. 2016) & Oryza sativa & - & $\begin{array}{l}\text { Xanthomonas oryzae pv. oryzae } \\
\text { X. oryzae pv. oryzicola } \\
\text { Erwinia carotovora subsp. atroseptica }\end{array}$ & & $\begin{array}{r}3.9 \mu \mathrm{g} / \mathrm{ml} \\
3.9 \mu \mathrm{g} / \mathrm{ml} \\
63 \mu \mathrm{g} / \mathrm{ml}\end{array}$ \\
\hline OsDef8 (Tantong et al. 2016) & Oryza sativa & - & $\begin{array}{l}\text { Xanthomonas oryzae pv. oryzae } \\
\text { X. oryzae pv. oryzicola } \\
\text { Erwinia carotovora subsp. atroseptica }\end{array}$ & & $\begin{array}{c}3.9 \mu \mathrm{g} / \mathrm{ml} \\
0.6 \mu \mathrm{g} / \mathrm{ml} \\
63 \mu \mathrm{g} / \mathrm{ml}\end{array}$ \\
\hline Pth-St1 (Moreno et al. 1994) & Solanum tuberosum & StDef1 & $\begin{array}{l}\text { Pseudomonas solanacearum } \\
\text { Clavibacter sepedonicus }\end{array}$ & $\begin{array}{l}2 \mu \mathrm{M} \\
0.3 \mu \mathrm{M}\end{array}$ & \\
\hline So-D2 (Segura et al. 1998) & Spinacia oleracea & SoDef2 & $\begin{array}{l}\text { Clavibacter sepedonicus } \\
\text { Ralstonia solanacearum }\end{array}$ & $\begin{array}{l}1 \mu \mathrm{M} \\
2 \mu \mathrm{M}\end{array}$ & \\
\hline So-D7 (Segura et al. 1998) & Spinacia oleracea & SoDef7 & $\begin{array}{l}\text { Clavibacter sepedonicus } \\
\text { Ralstonia solanacearum }\end{array}$ & $\begin{array}{l}0.1 \mu \mathrm{M} \\
1 \mu \mathrm{M}\end{array}$ & \\
\hline Tad1 (Koike et al. 2002) & Triticum aestivum & TaDef1 & Pseudomonas cichorii & $25 \mu \mathrm{g} / \mathrm{ml}$ & \\
\hline Tu-AMP1 (Fujimura et al. 2003) & Tulipa gesneriana & TgDef1 & $\begin{array}{l}\text { Erwinia carotovora subsp. carotovora } \\
\text { Agrobacterium tumefaciens } \\
\text { Clavibacter michiganensis } \\
\text { Curtobacterium flaccumfaciens pv. oortii }\end{array}$ & $\begin{array}{l}11 \mu \mathrm{g} / \mathrm{ml} \\
15 \mu \mathrm{g} / \mathrm{ml} \\
14 \mu \mathrm{g} / \mathrm{ml} \\
13 \mu \mathrm{g} / \mathrm{ml}\end{array}$ & \\
\hline Tu-AMP2 (Fujimura et al. 2003) & Tulipa gesneriana & TgDef2 & $\begin{array}{l}\text { Erwinia carotovora subsp. carotovora } \\
\text { Agrobacterium tumefaciens } \\
\text { Clavibacter michiganensis } \\
\text { Curtobacterium flaccumfaciens pv. oortii }\end{array}$ & $\begin{array}{l}15 \mu \mathrm{g} / \mathrm{ml} \\
17 \mu \mathrm{g} / \mathrm{ml} \\
17 \mu \mathrm{g} / \mathrm{ml} \\
15 \mu \mathrm{g} / \mathrm{ml}\end{array}$ & \\
\hline VaD1 (Chen et al. 2005) & Vigna angularis & VaDef1 & $\begin{array}{l}\text { Staphylococcus epidermis } \\
\text { Xanthomonas campestris pv. vesicatoria } \\
\text { Salmonella typhimurium }\end{array}$ & $\begin{array}{r}36.6 \mu \mathrm{g} / \mathrm{ml} \\
40.8 \mu \mathrm{g} / \mathrm{ml} \\
143.4 \mu \mathrm{g} / \mathrm{ml}\end{array}$ & \\
\hline ZmESR-6 (Balandín et al. 2005) & Zea mays & ZmDef6 & $\begin{array}{l}\text { Clavibacter sepedonicus } \\
\text { Xanthomonas campestris } \\
\text { Sinorhizobium meliloti }\end{array}$ & $\begin{array}{c}0.2 \mu \mathrm{M} \\
15 \mu \mathrm{M} \\
5 \mu \mathrm{M}\end{array}$ & \\
\hline
\end{tabular}

a The concentration of the peptides needed for $50 \%$ growth inhibition $\left(\mathrm{IC}_{50}\right)$ or minimal inhibitory concentration (MIC) values are listed for each defensin depending on which assay was used for the initial characterization.

$\mathrm{b}$ The $\mathrm{IC}_{50}$ is the concentration of defensin peptide that reduces bacterial growth by half.

${ }^{c}$ The MIC is the concentration of defensin peptide at which no bacterial growth is detected. 
coexpressed with pathogen-responsive genes. Additionally, Genevestigator (Hruz et al. 2008) was used to analyze the expression levels of candidate rice defensins in response to seven rice pathogens. OsDef7 and OsDef8 display potent antibacterial activity in vitro against Xanthomonas oryzae pv. oryzae, $X$. oryzae pv. oryzicola, and Erwinia carotovora subsp. atroseptica but do not show activity against gram-positive bacteria and are weakly active against phytopathogenic fungi (Tantong et al. 2016). With $\mathrm{IC}_{50}$ values as low as $0.6 \mu \mathrm{g} / \mathrm{ml}$, OsDef8 demonstrates greater antibacterial activity than OsDef7. When these defensins were transiently expressed in Nicotiana benthamiana leaves, increased resistance was shown against Xanthomonas campestris pv. glycines (Weerawanich et al. 2018).

MtDef5, a bi-domain defensin peptide containing two linked defensin domains, isolated from the model legume Medicago truncatula, displays antibacterial activity along with previously characterized extensive antifungal activity (Islam et al. 2017; Velivelli et al. 2018). MtDef5 was able to inhibit the gramnegative pathogen Xanthomonas campestris pv. campestris at a MIC value of $6 \mu \mathrm{M}$, but MtDef5 failed to inhibit the grampositive pathogen Clavibacter nebraskensis. This lack of antibacterial activity against $C$. nebraskensis was suggested to be a result of limited defensin binding to the thick, outer layer of peptidoglycan present in the cell walls of gram-positive bacteria (Velivelli et al. 2018).

Many more plant defensins have been discovered through genome analyses than through protein isolation and characterization (Maróti et al. 2015). However, because the specificity of antimicrobial activity is unique to each peptide, the activity of putative defensins needs to be tested experimentally. But there are some features that antibacterial plant defensins appear to share, which may allow for the prediction of antibacterial activity. J1-1, OsDef7, OsDef8, Tu-AMP2, and MtDef5 are among the few plant defensins that can form oligomeric structures, most commonly dimers, and they also have antibacterial activity (Fujimura et al. 2003; Guillén-Chable et al. 2017; Islam et al. 2017; Tantong et al. 2016). For mammalian defensins, the ability to form dimers is related to their antibacterial activity (Schibli et al. 2002). Even though all plant defensins that form dimers are not antibacterial, the ability to form dimers may be an indicator of antibacterial activity. Phylogenetic studies of plant defensins have demonstrated that the highest sequence homologies were between plant defensins that share the same biological activities (Zhu et al. 2005). Fabatin-2 and Cp-thionin II show structural and sequence homology to the well-characterized human antibacterial defensin HBD3 (Kraszewska et al. 2016). This may allow for the identification of conserved residues necessary for antibacterial activity. Also, buckwheat defensins, Fa-AMPs, are particularly rich in glycine residues, which suggests a connection with the glycine-rich peptide family that is known to display activity against gram-negative bacteria (Fujimura et al. 2003). Therefore, an abundance of glycine residues may be correlated with antibacterial activity. Additionally, studies could be performed that explore plant defensin bacterial lipid binding ability as an indicator of antibacterial activity. Lipid binding has been used to predict the antibacterial activity of defensins from fungi, mollusks, and arthropods (Schneider et al. 2010).

\section{DEFENSIN-LIKE PEPTIDES}

Plant genomes encode a large repertoire of defensin-like (DEFL) peptides with a conserved pattern of cysteine residues but with a highly variable mature peptide sequence (Mergaert et al. 2003; Silverstein et al. 2007). Based on sequence diversity, over 100 subgroups of DEFLs have been identified
(Silverstein et al. 2007). The functions of most members of this large gene family are largely unknown, although roles in plant development and plant-microbe interactions have been identified (Tesfaye et al. 2013). DEFLs that share secondary structural and functional homologies with plant defensins are the nodule-specific cysteine-rich peptides (NCRs) (Maróti et al. 2015). Also, similar to plant defensins, cationic NCRs (pI >9) have antimicrobial activity, while neutral and anionic peptides are inactive (Mikuláss et al. 2016). But, opposed to the eight cysteines found in plant defensins, NCRs have a conserved motif of four to six cysteine residues (Stonoha-Arther and Wang 2018). In the inverted repeat-lacking clade of legumes, NCRs are produced extensively in root nodules, and several NCRs have been shown to regulate interactions with rhizobial microsymbionts. In $M$. truncatula, NCR peptides are expressed exclusively in the nodules and are proposed to trigger terminal bacteroid differentiation of Sinorhizobium meliloti. Bacteroids are characterized by arrested cell division, cell elongation, DNA multiplication, and a partially permeabilized cell membrane, which appears to improve the efficiency of symbiosis (Van de Velde et al. 2010). Additionally, NCR peptides may eliminate rhizobial strains that use host resources to accumulate carbon resources but do not provide fixed nitrogen. Some NCR peptides have been shown to function in the elimination of infecting but unadapted rhizobial strains and to determine compatibility between the host and endosymbiont (Wang et al. 2017; Yang et al. 2017). In vitro, synthetic NCRs display broadspectrum activity against many bacteria, including rhizobia as well as fungi (Mergaert 2018). Two particularly well-studied M. truncatula NCRs, NCR247 and NCR335, display extensive antibacterial activity against both gram-positive and gramnegative bacteria although their spectra of activity were only partially overlapping, with NCR335 inhibiting a greater number of bacteria (Tiricz et al. 2013). Clavibacter michiganensis and Xanthomonas campestris were particularly sensitive to both NCRs, since bacterial growth was completely eliminated with peptide treatments of $50 \mu \mathrm{g} / \mathrm{ml}$ (Tiricz et al. 2013).

\section{ANTIBACTERIAL MODE OF ACTION}

In contrast to vertebrate defensins, the mode of action of most antibacterial plant defensins has not been investigated. Recently, Velivelli et al. (2018) examined the antibacterial activity of MtDef5 from M. truncatula. Through site-directed mutagenesis, the cationic amino acid residues found in the $\gamma$-core motif of MtDef5 were discovered to be essential for antibacterial activity. These residues were previously shown to be critical for antifungal activity (Islam et al. 2017). Treatment of $X$. campestris pv. campestris with MtDef5 causes morphological changes making the normally rod-shaped bacteria cells spherical or dumbbell-shaped, and these changes in morphology are associated with the loss of cell viability. MtDef5 was shown to permeabilize the bacterial plasma membrane and translocate into the cells of $X$. campestris pv. campestris (Velivelli et al. 2018). In vitro, MtDef5 binds to DNA, suggesting that the peptides may also inhibit DNA replication or gene transcription. VaD1, an antibacterial defensin isolated from azuki bean (Vigna angularis), was found to inhibit in vitro protein synthesis in a cell-free system derived from wheat germ (Chen et al. 2005). Additional studies are needed for understanding the modes of action of plant defensins against different species of bacteria.

Valuable insights into mechanisms of antibacterial activity can be gained from investigations into the MOA of NCRs. Synthetic NCRs were shown to induce membrane permeabilization and alter bacterial cell morphology, causing death of Sinorhizobium meliloti cells with MICs as low as $5 \mu \mathrm{M}$ 
(Van de Velde et al. 2010). NCR247 and NCR335 cause cell envelope damage to both the outer and inner bacterial membranes, resulting in the loss of membrane potential, which is proposed to be the primary reason for their antibacterial activity (Mikuláss et al. 2016). However, the two NCRs interact differently with bacterial membranes, though both appear to target the lipid matrix (Nagy et al. 2015). The transcriptome of Sinorhizobium meliloti cells treated with NCR247 and NCR335 was found to be similar to that of Staphylococcus aureus treated with the membrane-depolarizing agent carbonyl cyanide $m$-chlorophenyl-hydrazone (CCCP) (Tiricz et al. 2013). CCCP interferes with membrane potential and the proton gradient as well as inhibiting protein transport (Park et al. 1997). NCR247 binds to several intracellular targets to facilitate bacteroid formation. NCR247 binding to FtsZ, required for bacterial septum formation, inhibits cell division, binding to GroEL, a chaperone, was found to amplify NCR247-mediated processes, and binding to ribosomes was shown to inhibit translation (Farkas et al. 2014). Additionally, NCR247 treatments were found to block bacterial cell division through reducing the expression of the cell-cycle regulator ctrA (Penterman et al. 2014).

NCRs can be viewed as specialized, antibacterial peptides and can provide insights for understanding potential resistance mechanisms to antibacterial plant defensins. In the NCRrhizobial system, there is a coevolutionary relationship and molecular arms race that mimics the interaction between pathogen effectors and the plant immune system. For example, responding to the antibacterial activity of NCRs, some Sinorhizobium meliloti strains express a metallopeptidase, a host range restriction peptidase (HrrP) that degrades NCRs (Price et al. 2015). Through endosymbiont modifications to protect against host NCRs, we can infer potential host resistance mechanisms to antibacterial plant defensins.

BacA, a peptide transporter in Sinorhizobium meliloti, is required for bacterial survival in the presence of NCRs (Haag et al. 2011). The BacA knockout mutant is characterized by an altered distribution of the fatty acids in the lipopolysaccharide membrane (Ferguson et al. 2005). BacA is proposed to promote the uptake of NCRs and redirect them away from the bacterial membrane to limit membrane damage. This suggests that bacterial pathogens with a BacA homolog may not be susceptible to the antibacterial activity of NCRs and, likely, some plant defensins. NCR treatment induces the $\sigma^{32}$-stress factor RpoH1, a heat-shock protein transcription factor, in Sinorhizobium meliloti, and rpoH1 mutant nodules phenocopy the nodules from bacA mutants (Mitsui et al. 2004; Penterman et al. 2014). This suggests that RpoH1-regulated stress response may be required for bacterial survival since Sinorhizobium meliloti knockout mutants quickly die in the presence of NCRs (Penterman et al. 2014). Plant defensins may elicit this same stress response in bacteria and defeating this response may be necessary for antibacterial activity. Extracellular polysaccharides (EPS) and lipopolysaccharide membrane coatings affect the affinity of NCRs to rhizobial membranes (Mergaert 2018). Bacterial strains that have an EPS with few negatively charged succinate groups display increased susceptibility to NCRs compared with strains with greater amounts of succinate groups, which implies that this membrane modification shields against the antibacterial activity of NCR peptides (Simsek et al. 2007; Wang et al. 2018). Therefore, plant defensins may display less antibacterial activity against bacteria with membrane modifications that interfere with defensin binding. Similarly, bacterial pathogens of vertebrates have been shown to produce capsular polysaccharides to shield the membranes from defensins, inactivate or degrade the defensin peptide, and actively expel defensins from cells (Koprivnjak and Peschel 2011). Our current understanding of the bacterial targets of defensins and NCRs and bacterial host responses to defensins and NCRs is diagramed in Figure 1.

\section{PLANT DEFENSINS IN HUMAN AND ANIMAL HEALTH}

With the rising rates of antibiotic resistance in clinical bacterial strains, there is a renewed interest in alternative therapeutic compounds. Plant defensins are attractive candidates for antibiotic development. Pathogens are predicted to rarely develop resistant phenotypes because defensins specifically target the bacterial plasma membrane, do not interact with specific receptors, or likely have multiple targets. Thus, plant defensins may be an untapped reservoir for antibiotic and drug development for human and animal health.

When evaluated against human bacterial pathogens, several plant defensins had potent antibacterial activity. PaDef, a defensin from avocado (Persea americana var. drymifolia), displays antibacterial activity against Escherichia coli and

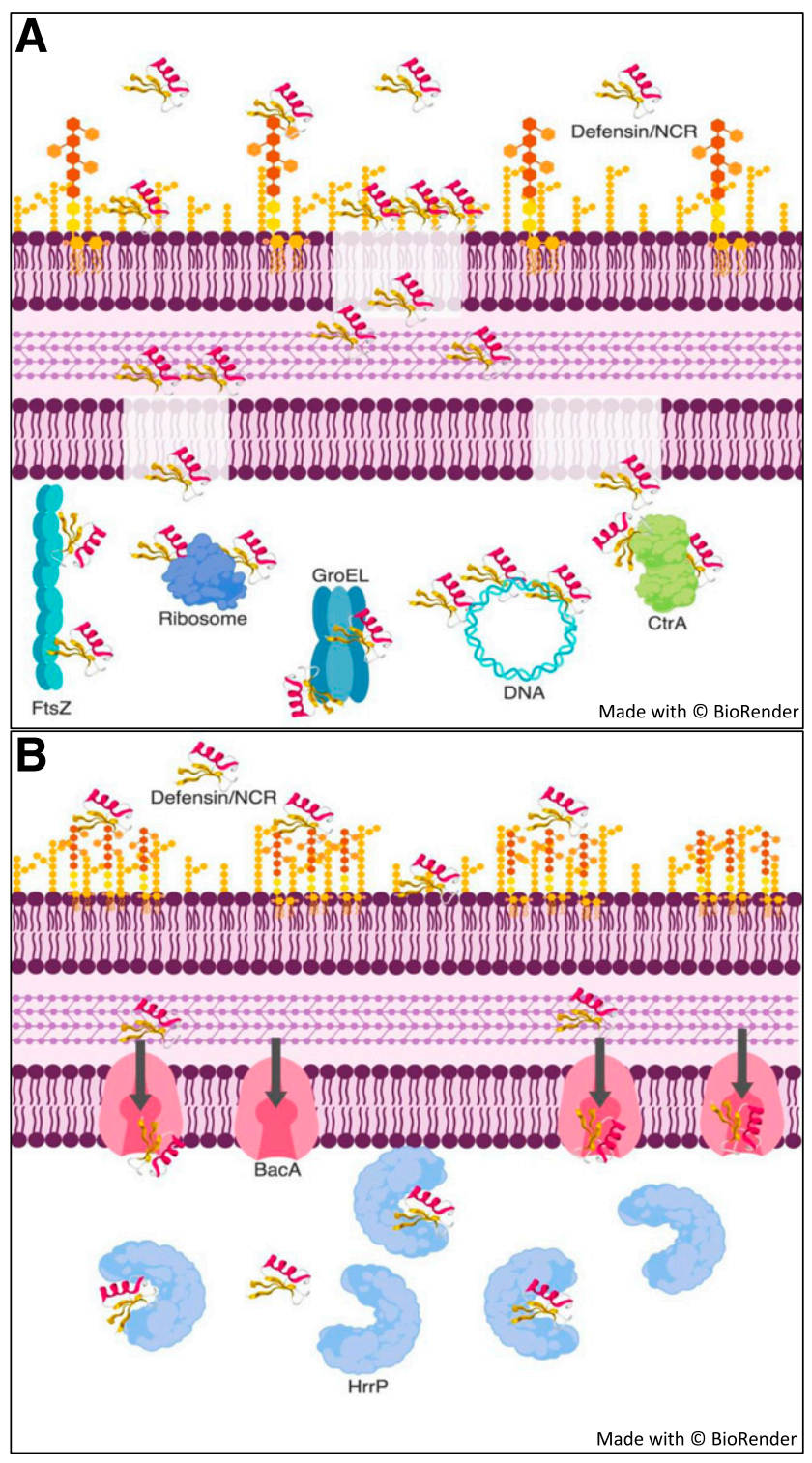

Fig. 1. Defensins and nodule-specific cysteine-rich peptides (NCRs) interfere with bacterial physiology. A, The membrane system for a typical gram-negative bacterium illustrates the bacterial targets of defensins and NCRs and B, the bacterial host responses to defensins and NCRs. The structure of a typical defensin peptide is shown by the colored ribbon structures. 
Staphylococcus aureus but failed to show antifungal activity against Candida albicans (Guzmán-Rodríguez et al. 2013). Since the synthesis of plant defensins can be difficult in prokaryotic expression systems due to improper posttranslational modifications, PaDef was expressed in the bovine endothelial cell line BE-E6E7, and the bacteria were evaluated in conditioned media containing the secreted PaDef at concentrations up to $100 \mu \mathrm{g} / \mathrm{ml}$ (Guzmán-Rodríguez et al. 2013). A defensin isolated from bell pepper (Capsicum annuиm), J1-1, exhibits antibacterial activity against Pseudomonas aeruginosa with a MIC of $250 \mu \mathrm{g} / \mathrm{ml}$ (Guillén-Chable et al. 2017). This interaction may be facilitated by the ability of J1-1 to bind to phosphoinositides and phosphatidic acid in vitro. Also, limenin, a defensin from lima bean (Phaseolus limensis), displays broad antibacterial activity against numerous human-associated bacterial species (Wong and $\mathrm{Ng} 2006$ ).

Against mammalian cancer cells, plant defensins have demonstrated specificity and cytotoxicity. PaDef is cytotoxic against K562 chronic myeloid leukemia cells with an $\mathrm{IC}_{50}$ value of $18.65 \mu \mathrm{M}$ (Flores-Alvarez et al. 2018). Surprisingly, PaDef was shown not to cause membrane permeation against K562 cells, which indicates that cytotoxicity is not related to cell membrane damage. In the breast cancer cell line MCF-7, PaDef was shown to induce apoptosis with an $\mathrm{IC}_{50}$ value of $27.23 \mu \mathrm{M}$ (Guzmán-Rodríguez et al. 2016). Also, NaD1 a defensin from sweet tobacco (Nicotiana alata) had an $\mathrm{IC}_{50}$ value of $10 \mu \mathrm{M}$ against leukemia cells (Poon et al. 2014). The cytotoxic mechanism of $\mathrm{NaD} 1$ against mammalian melanoma and leukemia cells at subacute concentrations was shown to be membranolytic rather than apoptotic, which implies that NaD1 and PaDef have different modes of action against cancer cells (Baxter et al. 2017).

\section{CONCLUSIONS AND PROSPECTS}

Plant defensins appear to be an untapped reservoir for developing plants with greater resistance to bacterial diseases as well as for combatting human and animal bacterial pathogens. Due to the possible misconception that plant defensins are solely antifungal and rarely display antibacterial activity, evaluation of defensins against bacterial pathogens may have been neglected in the past, and a reevaluation of previously characterized defensins for antibacterial activity is warranted. Expression of antibacterial defensins in genetically modified plants could lead to broad-spectrum disease resistance to provide a new tactic for combating economically important plant pathogens. The resistance conferred is likely to be highly durable and difficult to overcome, because plant defensins presumably target integral, conserved bacterial membrane components. Improving resistance to phytobacterial pathogens would contribute to substantial gains in crop yields. Additionally, these peptides have potential as applied plant protectants because the structure of defensins is compact and heat-stable, which suggests high environmental stability.

\section{LITERATURE CITED}

Ageitos, J. M., Sánchez-Pérez, A., Calo-Mata, P., and Villa, T. G. 2017. Antimicrobial peptides (AMPs): Ancient compounds that represent novel weapons in the fight against bacteria. Biochem. Pharmacol. 133:117-138.

Balandín, M., Royo, J., Gómez, E., Muniz, L. M., Molina, A., and Hueros, G. 2005. A protective role for the embryo surrounding region of the maize endosperm, as evidenced by the characterisation of ZmESR-6, a defensin gene specifically expressed in this region. Plant Mol. Biol. 58: 269-282.

Baxter, A. A., Poon, I. K., and Hulett, M. D. 2017. The plant defensin NaD1 induces tumor cell death via a non-apoptotic, membranolytic process. Cell Death Discov. 3:16102.
Broekaert, W. F., Terras, F. R., Cammue, B. P., and Osborn, R. W. 1995. Plant defensins: Novel antimicrobial peptides as components of the host defense system. Plant Physiol. 108:1353-1358.

Carvalho, A. de O., and Gomes, V. M. 2009. Plant defensins-Prospects for the biological functions and biotechnological properties. Peptides 30: 1007-1020.

Chen, G. H., Hsu, M. P., Tan, C. H., Sung, H. Y., Kuo, C. G., Fan, M. J., Chen, H. M., Chen, S., and Chen, C. S. 2005. Cloning and characterization of a plant defensin VaD1 from azuki bean. J. Agric. Food Chem. 53:982-988.

Cools, T. L., Struyfs, C., Cammue, B. P., and Thevissen, K. 2017. Antifungal plant defensins: Increased insight in their mode of action as a basis for their use to combat fungal infections. Future Microbiol. 12: 441-454.

De Coninck, B., Cammue, B. P. A., and Thevissen, K. 2013. Modes of antifungal action and in planta functions of plant defensins and defensinlike peptides. Fungal Biol. Rev. 26:109-120.

Elphinstone, J. G. 2005. The current bacterial wilt situation: A global overview. Pages 9-28 in: Bacterial Wilt Disease and the Ralstonia solanacearum Species Complex. C. Allen, P. Prior, and A. C. Hayward, eds. APS Press, St Paul, MN, U.S.A.

Farkas, A., Maróti, G., Durgő, H., Györgypál, Z., Lima, R. M., Medzihradszky, K. F., Kereszt, A., Mergaert, P., and Kondorosi, É. 2014. Medicago truncatula symbiotic peptide NCR247 contributes to bacteroid differentiation through multiple mechanisms. Proc. Natl. Acad. Sci. U.S.A. 111:5183-5188.

Ferguson, G. P., Datta, A., Carlson, R. W., and Walker, G. C. 2005 Importance of unusually modified lipid A in Sinorhizobium stress resistance and legume symbiosis. Mol. Microbiol. 56:68-80.

Fernandez de Caleya, R., Gonzalez-Pascual, B., García-Olmedo, F., and Carbonero, P. 1972. Susceptibility of phytopathogenic bacteria to wheat purothionins in vitro. Appl. Microbiol. 23:998-1000.

Flores-Alvarez, L. J., Guzmán-Rodríguez, J. J., López-Gómez, R., SalgadoGarciglia, R., Ochoa-Zarzosa, A., and López-Meza, J. E. 2018. PaDef defensin from avocado (Persea americana var. drymifolia) is cytotoxic to K562 chronic myeloid leukemia cells through extrinsic apoptosis. Int. J. Biochem. Cell Biol. 99:10-18.

Franco, O. L. 2011. Peptide promiscuity: An evolutionary concept for plant defense. FEBS Lett. 585:995-1000.

Franco, O. L., Murad, A. M., Leite, J. R., Mendes, P. A. M., Prates, M. V., and Bloch, C., Jr. 2006. Identification of a cowpea $\gamma$-thionin with bactericidal activity. FEBS J. 273:3489-3497.

Fujimura, M., Ideguchi, M., Minami, Y., Watanabe, K., and Tadera, K. 2004. Purification, characterization, and sequencing of novel antimicrobial peptides, Tu-AMP 1 and Tu-AMP 2, from bulbs of tulip (Tulipa gesneriana L.). Biosci. Biotechnol. Biochem. 68:571-577.

Fujimura, M., Minami, Y., Watanabe, K., and Tadera, K. 2003. Purification, characterization, and sequencing of a novel type of antimicrobial peptides, Fa-AMP1 and Fa-AMP2, from seeds of buckwheat (Fagopyrum esculentum Moench.). Biosci. Biotechnol. Biochem. 67:16361642 .

Gao, A. G., Hakimi, S. M., Mittanck, C. A., Wu, Y., Woerner, B. M., Stark, D. M., Shah, D. M., Liang, J., and Rommens, C. M. T. 2000. Fungal pathogen protection in potato by expression of a plant defensin peptide. Nat. Biotechnol. 18:1307-1310.

Gaspar, Y. M., McKenna, J. A., McGinness, B. S., Hinch, J., Poon, S., Connelly, A. A., Anderson, M. A., and Heath, R. L. 2014. Field resistance to Fusarium oxysporum and Verticillium dahliae in transgenic cotton expressing the plant defensin NaD1. J. Exp. Bot. 65:1541-1550.

Goyal, R. K., and Mattoo, A. K. 2014. Multitasking antimicrobial peptides in plant development and host defense against biotic/abiotic stress. Plant Sci. 228:135-149.

Guilhelmelli, F., Vilela, N., Albuquerque, P., Derengowski, L. da S., SilvaPereira, I., and Kyaw, C. M. 2013. Antibiotic development challenges: The various mechanisms of action of antimicrobial peptides and of bacterial resistance. Front. Microbiol. 4:353.

Guillén-Chable, F., Arenas-Sosa, I., Islas-Flores, I., Corzo, G., MartinezLiu, C., and Estrada, G. 2017. Antibacterial activity and phospholipid recognition of the recombinant defensin J1-1 from Capsicum genus. Protein Expr. Purif. 136:45-51.

Guzmán-Rodríguez, J. J., López-Gómez, R., Salgado-Garciglia, R., OchoaZarzosa, A., and López-Meza, J. E. 2016. The defensin from avocado (Persea americana var. drymifolia) PaDef induces apoptosis in the human breast cancer cell line MCF-7. Biomed. Pharmacother. 82: 620-627.

Guzmán-Rodríguez, J. J., López-Gómez, R., Suárez-Rodríguez, L. M., Salgado-Garciglia, R., Rodríguez-Zapata, L. C., Ochoa-Zarzosa, A., and López-Meza, J. E. 2013. Antibacterial activity of defensin PaDef from 
avocado fruit (Persea americana var. drymifolia) expressed in endothelial cells against Escherichia coli and Staphylococcus aureus. BioMed Res. Int. 2013:986273.

Haag, A. F., Baloban, M., Sani, M., Kerscher, B., Pierre, O., Farkas, A., Longhi, R., Boncompagni, E., Hérouart, D., Dall'angelo, S., Kondorosi, E., Zanda, M., Mergaert, P., and Ferguson, G. P. 2011. Protection of Sinorhizobium against host cysteine-rich antimicrobial peptides is critical for symbiosis. PLoS Biol. 9:e1001169.

Hao, G., Zhang, S., and Stover, E. 2017. Transgenic expression of antimicrobial peptide D2A21 confers resistance to diseases incited by Pseudomonas syringae pv. tabaci and Xanthomonas citri, but not Candidatus Liberibacter asiaticus. PLoS One 12:e0186810.

Hruz, T., Laule, O., Szabo, G., Wessendorp, F., Bleuler, S., Oertle, L., Widmayer, P., Gruissem, W., and Zimmermann, P. 2008. Genevestigator v3: A reference expression database for the meta-analysis of transcriptomes. Adv. Bioinforma. 2008:420747.

Islam, K. T., Velivelli, S. L. S., Berg, R. H., Oakley, B., and Shah, D. M. 2017. A novel bi-domain plant defensin MtDef5 with potent broadspectrum antifungal activity binds to multiple phospholipids and forms oligomers. Sci. Rep. 7:16157.

Koike, M., Okamoto, T., Tsuda, S., and Imai, R. 2002. A novel plant defensin-like gene of winter wheat is specifically induced during cold acclimation. Biochem. Biophys. Res. Commun. 298:46-53.

Koprivnjak, T., and Peschel, A. 2011. Bacterial resistance mechanisms against host defense peptides. Cell. Mol. Life Sci. 68:2243-2254.

Kraszewska, J., Beckett, M. C., James, T. C., and Bond, U. 2016. Comparative analysis of the antimicrobial activities of plant defensinlike and ultrashort peptides against food-spoiling bacteria. Appl. Environ. Microbiol. 82:4288-4298.

Kress, R. March 2015. Citrus plants resistant to citrus huanglongbing (ex greening) caused by Candidatus Liberibacter asiaticus (LAS) and bacterial canker caused by (Xanthomonas axonopodis pv. citri) (XAC). U.S. patent application no.14/468,998.

Lacerda, A. F., Vasconcelos, É. A. R., Pelegrini, P. B., and Grossi de Sa, M. F. 2014. Antifungal defensins and their role in plant defense. Front. Microbiol. 5:116.

Lee, T. H., Kim, Y. K., Pham, T. T. M., Song, S. I., Kim, J. K., Kang, K. Y., An, G., Jung, K. H., Galbraith, D. W., Kim, M., Yoon, U. H., and Nahm, B. H. 2009. RiceArrayNet: A database for correlating gene expression from transcriptome profiling, and its application to the analysis of coexpressed genes in rice. Plant Physiol. 151:16-33.

Mansfield, J., Genin, S., Magori, S., Citovsky, V., Sriariyanum, M., Ronald, P., Dow, M., Verdier, V., Beer, S. V., Machado, M. A., Toth, I., Salmond, G., and Foster, G. D. 2012. Top 10 plant pathogenic bacteria in molecular plant pathology. Mol. Plant Pathol. 13:614-629.

Maróti, G., Downie, J. A., and Kondorosi, É. 2015. Plant cysteine-rich peptides that inhibit pathogen growth and control rhizobial differentiation in legume nodules. Curr. Opin. Plant Biol. 26:57-63.

Mergaert, P. 2018. Role of antimicrobial peptides in controlling symbiotic bacterial populations. Nat. Prod. Rep. 35:336-356.

Mergaert, P., Nikovics, K., Kelemen, Z., Maunoury, N., Vaubert, D. Kondorosi, A., and Kondorosi, E. 2003. A novel family in Medicago truncatula consisting of more than 300 nodule-specific genes coding for small, secreted polypeptides with conserved cysteine motifs. Plant Physiol. 132:161-173.

Mew, T., Alvarez, A., Leach, J., and Swings, J. 1993. Focus on bacterial blight of rice. Plant Dis. 77:5-12

Mikuláss, K. R., Nagy, K., Bogos, B., Szegletes, Z., Kovács, E., Farkas, A., Váró, G., Kondorosi, É., and Kereszt, A. 2016. Antimicrobial nodulespecific cysteine-rich peptides disturb the integrity of bacterial outer and inner membranes and cause loss of membrane potential. Ann. Clin. Microbiol. Antimicrob. 15:43.

Mirkov, T. E., and Gonzalez-Ramos, J. April 2014. Pathogen resistant citrus compositions, organisms, systems, and methods. U.S. Patent application No.14/139,791.

Mitsui, H., Sato, T., Sato, Y., Ito, N., and Minamisawa, K. 2004. Sinorhizobium meliloti RpoH1 is required for effective nitrogen-fixing symbiosis with alfalfa. Mol. Genet. Genomics 271:416-425.

Montesinos, E. 2007. Antimicrobial peptides and plant disease control. FEMS Microbiol. Lett. 270:1-11.

Moreno, M., Segura, A., and García-Olmedo, F. 1994. Pseudothionin-St1, a potato peptide active against potato pathogens. Eur. J. Biochem. 223: 135-139.

Morgera, F., Antcheva, N., Pacor, S., Quaroni, L., Berti, F., Vaccari, L., and Tossi, A. 2008. Structuring and interactions of human $\beta$-defensins 2 and 3 with model membranes. J. Pept. Sci. 14:518-523.

Nagy, K., Mikuláss, K. R., Végh, A. G., Kereszt, A., Kondorosi, E., Váró, G., and Szegletes, Z. 2015. Interaction of cysteine-rich cationic antimicrobial peptides with intact bacteria and model membranes Gen. Physiol. Biophys. 34:135-144.

Osborn, R. W., De Samblanx, G. W., Thevissen, K., Goderis, I., Torrekens, S., Van Leuven, F., Attenborough, S., Rees, S. B., and Broekaert, W. F. 1995. Isolation and characterisation of plant defensins from seeds of Asteraceae, Fabaceae, Hippocastanaceae and Saxifragaceae. FEBS Lett. 368:257-262

Parisi, K., Shafee, T. M. A., Quimbar, P., van der Weerden, N. L., Bleackley, M. R., and Anderson, M. A. 2018. The evolution, function and mechanisms of action for plant defensins. Semin. Cell Dev. Biol. . doi. org/10.1016/j.semcdb.2018.02.004

Park, J. W., Lee, S. Y., Yang, J. Y., Rho, H. W., Park, B. H., Lim, S. N., Kim, J. S., and Kim, H. R. 1997. Effect of carbonyl cyanide mchlorophenylhydrazone (CCCP) on the dimerization of lipoprotein lipase. Biochim. Biophys. Acta 1344:132-138.

Penterman, J., Abo, R. P., De Nisco, N. J., Arnold, M. F. F., Longhi, R., Zanda, M., and Walker, G. C. 2014. Host plant peptides elicit a transcriptional response to control the Sinorhizobium meliloti cell cycle during symbiosis. Proc. Natl. Acad. Sci. U.S.A. 111:3561-3566.

Poon, I. Kh., Baxter, A. A., Lay, F. T., Mills, G. D., Adda, C. G., Payne, J. A. E., Phan, T. K., Ryan, G. F., White, J. A., Veneer, P. K., van der Weerden, N. L., Anderson, M. A., Kvansakul, M., and Hulett, M. D. 2014. Phosphoinositide-mediated oligomerization of a defensin induces cell lysis. eLife 3:e01808.

Price, P. A., Tanner, H. R., Dillon, B. A., Shabab, M., Walker, G. C., and Griffitts, J. S. 2015. Rhizobial peptidase HrrP cleaves host-encoded signaling peptides and mediates symbiotic compatibility. Proc. Natl. Acad. Sci. U.S.A. 112:15244-15249.

Rautenbach, M., Troskie, A. M., and Vosloo, J. A. 2016. Antifungal peptides: To be or not to be membrane active. Biochimie 130:132-145.

Sagaram, U. S., Pandurangi, R., Kaur, J., Smith, T. J., and Shah, D. M. 2011 Structure-activity determinants in antifungal plant defensins MsDef1 and MtDef4 with different modes of action against Fusarium graminearum. PLoS One 6:e18550.

Sass, V., Pag, U., Tossi, A., Bierbaum, G., and Sahl, H.-G. 2008. Mode of action of human $\beta$-defensin 3 against Staphylococcus aureus and transcriptional analysis of responses to defensin challenge. Int. J. Med. Microbiol. 298:619-633.

Schibli, D. J., Hunter, H. N., Aseyev, V., Starner, T. D., Wiencek, J. M., McCray, P. B., Jr., Tack, B. F., and Vogel, H. J. 2002. The solution structures of the human $\beta$-defensins lead to a better understanding of the potent bactericidal activity of HBD3 against Staphylococcus aureus. J. Biol. Chem. 277:8279-8289.

Schneider, T., Kruse, T., Wimmer, R., Wiedemann, I., Sass, V., Pag, U., Jansen, A., Nielsen, A. K., Mygind, P. H., Raventós, D. S., Neve, S., Ravn, B., Bonvin, A. M. J. J., De Maria, L., Andersen, A. S., Gammelgaard, L. K., Sahl, H. G., and Kristensen, H. H. 2010. Plectasin, a fungal defensin, targets the bacterial cell wall precursor lipid II. Science 328:1168-1172.

Segura, A., Moreno, M., Molina, A., and García-Olmedo, F. 1998. Novel defensin subfamily from spinach (Spinacia oleracea). FEBS Lett. 435 159-162.

Shafee, T. M. A., Lay, F. T., Hulett, M. D., and Anderson, M. A. 2016. The defensins consist of two independent, convergent protein superfamilies. Mol. Biol. Evol. 33:2345-2356.

Sharma, K. K., Pothana, A., Prasad, K., Shah, D., Kaur, J., Bhatnagar, D., Chen, Z.-Y., Raruang, Y., Cary, J. W., Rajasekaran, K., Sudini, H. K., and Bhatnagar-Mathur, P. 2018. Peanuts that keep aflatoxin at bay: A threshold that matters. Plant Biotechnol. J. 16:1024-1033.

Shenkarev, Z. O., Gizatullina, A. K., Finkina, E. I., Alekseeva, E. A., Balandin, S. V., Mineev, K. S., Arseniev, A. S., and Ovchinnikova, T. V. 2014. Heterologous expression and solution structure of defensin from lentil Lens culinaris. Biochem. Biophys. Res. Commun. 451: 252-257.

Silverstein, K. A. T., Moskal, W. A., Jr., Wu, H. C., Underwood, B. A., Graham, M. A., Town, C. D., and VandenBosch, K. A. 2007. Small cysteine-rich peptides resembling antimicrobial peptides have been under-predicted in plants. Plant J. 51:262-280.

Simsek, S., Ojanen-Reuhs, T., Stephens, S. B., and Reuhs, B. L. 2007. Strain-ecotype specificity in Sinorhizobium meliloti-Medicago truncatula symbiosis is correlated to succinoglycan oligosaccharide structure. J. Bacteriol. 189:7733-7740.

Spelbrink, R. G., Dilmac, N., Allen, A., Smith, T. J., Shah, D. M., and Hockerman, G. H. 2004. Differential antifungal and calcium channelblocking activity among structurally related plant defensins. Plant Physiol. 135:2055-2067.

Stonoha-Arther, C., and Wang, D. 2018. Tough love: Accommodating intracellular bacteria through directed secretion of antimicrobial 
peptides during the nitrogen-fixing symbiosis. Curr. Opin. Plant Biol. 44: 155-163.

Tam, J. P., Wang, S., Wong, K. H., and Tan, W. L. 2015. Antimicrobial peptides from plants. Pharmaceuticals 8:711-757.

Tantong, S., Pringsulaka, O., Weerawanich, K., Meeprasert, A., Rungrotmongkol, T., Sarnthima, R., Roytrakul, S., and Sirikantaramas, S. 2016. Two novel antimicrobial defensins from rice identified by gene coexpression network analyses. Peptides 84:7-16.

Tesfaye, M., Silverstein, K. A. T., Nallu, S., Wang, L., Botanga, C. J., Gomez, S. K., Costa, L. M., Harrison, M. J., Samac, D. A., Glazebrook, J., Katagiri, F., Gutierrez-Marcos, J. F., and Vandenbosch, K. A. 2013. Spatio-temporal expression patterns of Arabidopsis thaliana and Medicago truncatula defensin-like genes. PLoS One 8:e58992.

Tiricz, H., Szücs, A., Farkas, A., Pap, B., Lima, R. M., Maróti, G., Kondorosi, É., and Kereszt, A. 2013. Antimicrobial nodule-specific cysteine-rich peptides induce membrane depolarization-associated changes in the transcriptome of Sinorhizobium meliloti. Appl. Environ. Microbiol. 79:6737-6746.

Van de Velde, W., Zehirov, G., Szatmari, A., Debreczeny, M., Ishihara, H., Kevei, Z., Farkas, A., Mikulass, K., Nagy, A., Tiricz, H., Satiat-Jeunemaître, B., Alunni, B., Bourge, M., Kucho, K., Abe, M., Kereszt, A., Maroti, G., Uchiumi, T., Kondorosi, E., and Mergaert, P. 2010. Plant peptides govern terminal differentiation of bacteria in symbiosis. Science 327:1122-1126.

van der Weerden, N. L., and Anderson, M. A. 2013. Plant defensins: Common fold, multiple functions. Fungal Biol. Rev. 26:121-131.

Velivelli, S. L. S., Islam, K. T., Hobson, E., and Shah, D. M. 2018. Modes of action of a bi-domain plant defensin MtDef5 against a bacterial pathogen Xanthomonas campestris. Front. Microbiol. 9:934.

Vriens, K., Cammue, B. P. A., and Thevissen, K. 2014. Antifungal plant defensins: Mechanisms of action and production. Molecules 19: $12280-12303$
Wang, Q., Liu, J., Li, H., Yang, S., Körmöczi, P., Kereszt, A., and Zhu, H. 2018. Nodule-specific cysteine-rich peptides negatively regulate nitrogen-fixing symbiosis in a strain-specific manner in Medicago truncatula. Mol. Plant-Microbe Interact 31:240-248.

Wang, Q., Yang, S., Liu, J., Terecskei, K., Ábrahám, E., Gombár, A., Domonkos, A., Szücs, A., Körmöczi, P., Wang, T., Fodor, L., Mao, L. Fei, Z., Kondorosi, É., Kaló, P., Kereszt, A., and Zhu, H. 2017. Hostsecreted antimicrobial peptide enforces symbiotic selectivity in Medicago truncatula. Proc. Natl. Acad. Sci. U.S.A. 114:6854-6859.

Weerawanich, K., Webster, G., Ma, J. K. C., Phoolcharoen, W., and Sirikantaramas, S. 2018. Gene expression analysis, subcellular localization, and in planta antimicrobial activity of rice (Oryza sativa L.) defensin 7 and 8. Plant Physiol. Biochem. 124:160-166.

Wiegand, I., Hilpert, K., and Hancock, R. E. W. 2008. Agar and broth dilution methods to determine the minimal inhibitory concentration (MIC) of antimicrobial substances. Nat. Protoc. 3:163-175.

Wong, J. H., and Ng, T. B. 2006. Limenin, a defensin-like peptide with multiple exploitable activities from shelf beans. J. Pept. Sci. 12:341-346.

Yang, S., Wang, Q., Fedorova, E., Liu, J., Qin, Q., Zheng, Q., Price, P. A. Pan, H., Wang, D., Griffitts, J. S., Bisseling, T., and Zhu, H. 2017. Microsymbiont discrimination mediated by a host-secreted peptide in Medicago truncatula. Proc. Natl. Acad. Sci. U.S.A. 114:6848-6853.

Zhang, Y., and Lewis, K. 1997. Fabatins: New antimicrobial plant peptides. FEMS Microbiol. Lett. 149:59-64.

Zhang, Y., Lu, W., and Hong, M. 2010. The membrane-bound structure and topology of a human $\alpha$-defensin indicate a dimer pore mechanism for membrane disruption. Biochemistry 49:9770-9782.

Zhu, S., Gao, B., and Tytgat, J. 2005. Phylogenetic distribution, functional epitopes and evolution of the CS $\alpha \beta$ superfamily. Cell. Mol. Life Sci. 62 : 2257-2269. 